\title{
PEMANFAATAN HEWAN ECHINODERMATA SEBAGAI MEDIA PEMBELAJARAN TERHADAP HASIL BELAJAR SISWA KELAS VII SMP NEGERI PERSIAPAN DI KAMPUNG YENBESER DISTRIK WAIGEO SELATAN KABUPATEN RAJA AMPAT.
}

\author{
CHRISTINA LEVEGA HELWEND
}

SMP Negeri Persiapan Di Kampung Yenbeser Distrik Waigeo Selatan Kabupaten Raja Ampat

\begin{abstract}
ABSTRAK
Hasil belajar merupakan tujuan akhir dilaksanakannya kegiatan pembelajaran di sekolah. Hasil belajar siswa kelas VII SMP Negeri Persiapan Yenbeser sebelum penelitian ini di laksanakan belum mengalami peningkatan dan masih berada di bawa nilai KKM (65), setelah pelaksanakan penelitian ini dan media pembelajaran yang digunakan yaitu spesimen hewan Echinodermata maka di peroleh hasil belajar yang meningkat signifikan. Semua hasil belajar tersebut merupakan hasil dari suatu interaksi tindak belajar dan tindak mengajar. Untuk itu penelitian ini bertujuan untuk mengetahui pemanfaatan hewan Echinodermata sebagai media pembelajaran terhadap Hasil Belajar siswa kelas VII di SMP Negeri Persiapan Yenbeser Kabupaten Raja Ampat pada bulan September 2017, dengan menggunakan populasi seluruh siswa SMP N Persiapan Yenbeser Kabupaten Raja Ampat dan sampel yang digunakan adalah siswa pada kelas VII. Metodologi penelitian yang digunakan adalah penelitian kuantitatif pre-eksperimental dengan desain one group pretest-postest. Instrumen yang digunakan adalah tes, yang sebelumnya diuji validitas dan uji reliabilitas, hasil uji validitas pada instrument yang digunakan valid. Data tes berdistribusi normal. Hasil uji t-test paired sampel di dapati bahwa nilai rata-rata tes awal adalah 62,00 dan nilai rata-rata tes akhir adalah 85,00 dengan memperhitungkan nilai $t_{\text {hitung }}$ dan $t_{\text {tabel }}$ yakni $t_{\text {hitung }}>$ $\mathrm{t}_{\text {tabel }}(15,057>0,83311)$ sehingga ada perbedaan pada hasil belajar sebelum dan sesudah menggunakan spesimen hewan echinodermata sebagai media pembelajaran dan dari hasil tes siswa yang diperoleh bahwa pemanfaatan hewan echinodermata tersebut efektif sebagai media pembelajaran.
\end{abstract}

Kata kunci: Hasil Belajar, Pemanfaatan Hewan Echinodermata.

\begin{abstract}
The study result was a main purpose of studying and learning process at school, furthermore, the test results of the students in grade one were more significant, in spite of the results before the research done here were bad, they lower than 65 as a target of the students' scores which are must be obtained, but after using the echinodermata as a learning media, the result would be rouse up significantly. Therefore, the purpose of this research was to know the benefit of echinodermata animal as a learning media in effecting students' work results of the grade one in learning biology at junior high school of Yenbeser Village South Waigeo Subdistric. Here was successfully integrated work from students and teacher by teaching and learning process at school. From this on, the researcher used all students at the school to become a population and those others ten in grade one might be a sample. Moreover, quantity method was pre-experimental used with one group designed by using the pre-test and pos-test were a way which was researcher used to measure the capability of students. Test was an instrument or tool that researcher used, but it should be validated before, so that it could be re-able and it might be used as a proper instrument. According to the data of the test in the grade one, that instrument might be used. Distribution of the data of the test would be a normal. The result of the beginning test was 62, 00 and the second one would be 85, 00 according to the value of $t_{\text {counted }}$ and value of $t_{\text {table }}(15,057>0,83311)$ it can be compared that the result of the test before was good and the second one was more upper. Whereas the animal of echinodermata can be used as a media in teaching biology at grade one of junior high school of Yenbeser Village South Waigeo Subdistric, Raja Ampat Regency.
\end{abstract}

Key word: result of study, beneficial of Echinodermta animal

\section{PENDAHULUAN}

Undang-Undang Republik Indonesia No. 20 tahun 2003 pasal 1 ayat 1 tentang Sistem Pendidikan Nasional (SISDIKNAS) menyebutkan bahwa "pendidikan adalah usaha sadar dan terencana untuk dapat mewujudkan suasana belajar dan proses pembelajaran agar siswa secara aktif mengembangkan potensi dirinya untuk memiliki kekuatan spiritual keagamaan, pengendalian diri, kepribadian, kecerdasan, dan akhlak mulia, serta keterampilan yang diperlukan dirinya, masyarakat, bangsa dan negara" (azroqu, 2013).

Satyasa (2009) menyebutkan bahwa Peserta didik akan memperoleh pengalaman nyata serta dapat memadukan antara teori dan kondisi nyata yang ada di lapangan, sehingga mudah diingat dan akan melekat kuat dan tahan lama dalam diri peserta didik di samping itu suasana akan lebih segar dan tentunya akan menarik peserta didik untuk terus mencari dan menemukan sesuatu, dimana peserta didik diajak untuk menemukan sesuatu dan menyimpulkan konsep 
sendiri. Diharapkan dengan model ini peserta didik akan menghargai proses pencarian dan penemuan, sehingga pembelajaran akan lebih berkualitas dan bermakna bagi peserta didik .

Badan Standar Nasional Pendidikan (2006) Biologi sebagai salah satu bidang IPA menyediakan berbagai pengalaman belajar untuk memahami konsep dan proses sains, sehingga siswa perlu dibantu untuk mengembangkan keterampilan proses sehingga mereka mampu menjelajahi dan memahami alam sekitar.

Menurut Hamalik, (2006) proses belajar adalah dalam rangka mempengaruhi siswa agar dapat menyesuaikan terhadap diri sendiri maupun dengan lingkungannya supaya menimbulkan perubahan dalam dirinya yang memungkinkan berfungsi dalam kehidupan masyarakat.

Hasil belajar merupakan tujuan akhir dilaksanakannya kegiatan pembelajaran di sekolah. Akhir dari proses belajar adalah perolehan suatu hasil belajar siswa. Semua hasil belajar tersebut merupakan hasil dari suatu interaksi tindak belajar dan tindak mengajar. Hasil observasi peneliti pada SMP Negeri Persiapan Yenbeser ternyata guru lebih banyak menggunakan buku sebagai media pembelajaran, sementara disekitar lingkungan sekolah bahkan wilayah tersebut banyak tersedia sumberdaya alam yang dapat digunakan sebagai media pembelajaran untuk meningkatkan hasil belajar siswa. Hal ini membuat siswa lebih cepat bosan dalam mengikuti atau menerima pelajaran yang diberikan oleh guru.

Berdasarkan latar belakang di atas maka peneliti tertarik untuk mengangkat judul tentang Pemanfaatan Hewan Echinodermata sebagai Media Pembelajaran terhadap Hasil Belajar Siswa Kelas VII SMP Negeri Persiapan Di Kampung Yenbeser Distrik Waigeo Selatan Kabupaten Raja Ampat. Tujuan dari penelitian ini adalah untuk mengetahui pemanfaatan hewan Echinodermata sebagai Media Pembelajaran terhadap hasil belajar siswa kelas VII di SMP Negeri Persiapan Yenbeser Kabupaten Raja Ampat.

\section{METODE PENELITIAN}

Jenis penelitian ini menggunakan pendekatan kuantitatif , Sugiyono (2014) mengatakan bahwa pendekatan kuantitatif yaitu proses menemukan pengertian menggunakan data berupa angka sebagai alat untuk menemukan keterangan mengenai apa yang ingin diketahui.

Dalam penelitian ini menggunakan desain pra-eksperimental dengan One Group Pretest-Postest Design.

Penelitian ini dilaksanakan di SMP Negeri Persiapan Yenbeser, Kampung Yenbeser Distrik Waigeo Selatan Kabupaten Raja Ampat. Waktu pelaksanaan penelitian ini pada tanggal $19-23$ September 2017

Sampel adalah bagian dari jumlah dan karakteristik yang dimiliki oleh populasi (Sugiyono,
2009). Penelitian ini menggunakan sampel pada siswa kelas VII di SMP Negeri Persiapan Yenbeser Kabupaten Raja Ampat. Teknik pengambilan sampel yaitu dengan cara purposive sampling, dimana pada mulanya peneliti mengidentifikasi karakter dari pada siswa kemudian peneliti mulai menetapkan sampelnya.

Penelitian ini menggunakan tes berupa tes objektif berbentuk pilihan ganda, tes dilaksanakan pada saat pretest dan postets. Instrument yang digunakan dalam pengambilan data pada penelitian ini dengan menggunakan tes hasil belajar (pretes dan postes).

Uji validitas adalah kebenaran dan keabsahan instrument penelitian yang digunakan. Sebuah instrument dikatakan valid apabila mampu mengukur apa yang diinginkan. Uji validitas dalam penelitian ini menggunakan rumus korelasi Product Moment Person, dimana valid atau tidaknya instrument dapat diketahui dengan membandingkan indeks korelasi Product Moment Person. Untuk mengetahui validitas butir pernyataan yang disusun oleh peneliti maka diuji validitasnya dengan rumus Product Moment Person sebagai berikut (Kurniawan, 2011) :

Pada uji validitas, peneliti menggunakan software SPSS, dimana instrumen dikatakan valid yaitu apabila signifikannya $5 \%$ artinya bila probabilitas hasil korelasi < 0,05 maka instrumen dikatakan tidak valid dan sebaliknya, jika hasil korelasi > dari 0,05 maka instrumen tersebut dikatakan valid.

Uji realibilitas adalah indeks yang menunjukkan sejauh mana suatu alat pengukur dapat dipercaya atau dapat diandalkan. Reliabilitas menunjukkan sejauh mana hasil pengukuran tetap konsisten bila dilakukan pengukuran dua kali atau lebih terhadap gejala yang sama, dengan alat pengukur yang sama. Untuk 0mengetahui realibilitas butir pernyataan maka menggunakan teknik Alpha Croncbah

Data yang terkumpul dalam penelitian ini dianalisis dengan menggunakan aplikasi statistik untuk mempermudah penelitian dalam perhitungan. Teknik analisis data pada penelitian ini dibagi menjadi:

Uji normalitas data dimaksudkan untuk memperlihatkan bahwa data sampel berasal dari berasal dari populasi yang berdistribusi normal. Ada beberapa teknik yang dapat digunakan untuk menguji normalitas data, antara lain uji chi-kuadrat, uji lilliefors, dan uji kolmogorov-smirnov. Pada penelitian ini menggunakan uji Kolmogrov-Smirnov.

Validitas adalah suatu ukuran yang menunjukkan tingkat kevalidan atau kesahihan suatu instrument. Sebuah item dikatakan valid apabila mempunyai dukungan yang besar terhadap skor total. Skor pada item menyebabkan skor total menjadi tinggi atau rendah. Uji validitas digunakan untuk menentukan validitas item soal menggunakan rumus korelasi product moment. 
Analisis uji hipotesis menggunakan uji t (uji beda). Uji $t$ ini untuk mengetahui pengaruh pemanfaatan hewan echinodermata terhadap hasil belajar siswa. Uji t dilakukan dengan asumsi kriteria pengujian adalah jika $\mathrm{t}_{\text {hitung }}>\mathrm{t}_{\text {tabel }}$ maka $\mathrm{H}_{0}$ ditolak dan $\mathrm{H}_{\mathrm{a}}$ diterima artinya terdapat pengaruh antara variabel bebas dan terikat. Sebaliknya jika $t_{\text {hitung }}<\mathrm{t}$ tabel maka $\mathrm{H}_{0}$ diterima dan $\mathrm{H}_{\mathrm{a}}$ ditolak artinya tidak ada perbedaan antara variabel bebas dengan variabel terikat.

\section{PEMBAHASAN}

Data hasil penelitian ini di peroleh dari penelitian yang diterapkan pada Sekolah Menengah Pertama (SMP) Negeri Persiapan Yenbeser. Penelitian ini menggunakan satu kelas yaitu kelas VII dengan jumlah siswa 10 siswa sebagai sampel penelitian.

Data penelitian ini berupa tes awal dan tes akhir yang diberlakukan pada kelas VII, untuk mengetahui pemanfaatan hewan invertebrata terhadap hasil belajar siswa. Tes awal dilakukan sebelum siswa diberi perlakuan dan untuk mengetahui hasil belajar siswa setelah diberi perlakuan siswa diberi tes akhir.

Hasil tes sebelum dan sesudah perlakuan yang diberikan kepada siswa berupa tes pilihan ganda.

Instrumen tes awal diberikan kepada siswa sebelum diberi perlakuan. Untuk mengetahui hasil tes siswa sebelum perlakuan, dan berikut adalah data hasil pemberian tes awal siswa kelas VII.

Tabel 4.1 Hasil Nilai Pretest Kelas VII

\begin{tabular}{lccc}
\hline \multicolumn{1}{c}{ Nama } & Jenis Kelamin & Nilai & Ket \\
\hline Dolfinus Wawiyai & $\mathrm{L}$ & 50 & $\mathrm{TL}$ \\
Enos Kolomsusu & $\mathrm{L}$ & 60 & $\mathrm{TL}$ \\
Fredika Mambrasar & $\mathrm{P}$ & 50 & $\mathrm{TL}$ \\
Irene Mayor & $\mathrm{P}$ & 50 & $\mathrm{TL}$ \\
Jendri Tanikwele & $\mathrm{L}$ & 80 & $\mathrm{~L}$ \\
Megi Wabiser & $\mathrm{L}$ & 60 & $\mathrm{TL}$ \\
Margaretha Imbir & $\mathrm{P}$ & 70 & $\mathrm{~L}$ \\
Pontinus Imbir & $\mathrm{L}$ & 70 & $\mathrm{~L}$ \\
Sarah Mambrasar & $\mathrm{P}$ & 80 & $\mathrm{~L}$ \\
Winer Dimara & $\mathrm{L}$ & 50 & $\mathrm{TL}$ \\
\hline
\end{tabular}

Tabel 4.2 Rangkuman hasil pretest siswa kelas VII

\begin{tabular}{|lc|}
\hline Statistik Deskriptif & $\begin{array}{c}\text { Perolehan skor } \\
\text { Kelas VII }\end{array}$ \\
\hline Jumlah Siswa & 10 \\
Minimum $\left(\mathrm{X}_{\min }\right)$ & 50 \\
Maksimum $\left(\mathrm{X}_{\max }\right)$ & 80 \\
Jumlah Nilai $($ Sum $)$ & 620 \\
Mean $(\mathrm{X})$ & 62.00 \\
Simpangan Baku(S) & 12.293 \\
\hline
\end{tabular}

Tabel 4.2 Menunjukan bahwa pada tes awal untuk kelas VII yang berjumlah 10 siswa diperoleh nilai terendah yaitu 50, nilai tertinggi 80 , dan jumlah nilai seluruh siswa 620 dengan kemampuan rata-rata seluruh siswa 62,00 dari nilai simpangan baku yang diperoleh yaitu sebesar 12,293.

Dari data tes awal siswa kelas VII, diperoleh data dalam bentuk distribusi frekuensi untuk melihat frekuensi nilai yang diperoleh pada kelas VII

Tabel 4.3 Distribusi Frekuensi Skor Awal Siswa Kelas VII

\begin{tabular}{rrcc}
\hline No & Interval & Frekuensi & Presentasi (\%) \\
\hline 1. & $50-55$ & 4 & $40 \%$ \\
2. & $56-61$ & - & - \\
3. & $62-67$ & - & - \\
4. & $68-73$ & 2 & $20 \%$ \\
5. & $74-79$ & 2 & $20 \%$ \\
6. & $80-85$ & 2 & $20 \%$ \\
\hline & Jumlah & 10 & $100 \%$ \\
\hline
\end{tabular}

Wismarini dkk (2014) 


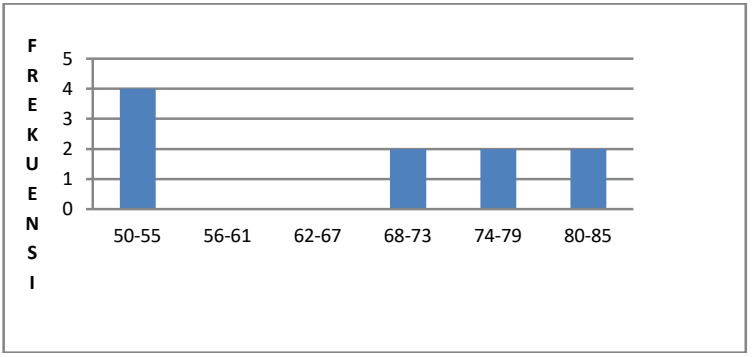

Gambar 4.1 Grafik Distribusi Frekuensi Skor Awal Siswa Kelas VII

Sesudah pemberian tes awal ,sampel akan diberi perlakuan untuk mengetahui apakah terdapat perbedaan antara hasil tes awal dan hasil tes akhir, berikut adalah hasil tes akhir siswa kelas VII.

Tabel 4.4 Hasil Postest Kelas VII

\begin{tabular}{lcc}
\hline \multicolumn{1}{c}{ Nama } & Nilai & Ket \\
\hline Dolfinus Wawiyai & 70 & $\mathrm{~L}$ \\
Enos Kolomsus & 80 & $\mathrm{~L}$ \\
Fredika Mambrasar & 80 & $\mathrm{~L}$ \\
Irene Mayor & 80 & $\mathrm{~L}$ \\
Jendri Tanikwele & 100 & $\mathrm{~L}$ \\
Megi Wabiser & 80 & $\mathrm{~L}$ \\
Margaretha Imbir & 90 & $\mathrm{~L}$ \\
Pontinus Imbir & 90 & $\mathrm{~L}$ \\
Sarah Mambrasar & 100 & $\mathrm{~L}$ \\
Winer Dimara & 80 & $\mathrm{~L}$ \\
\hline
\end{tabular}

Tabel 4.5 Rangkuman Hasil Postest Siswa Kelas VII

\begin{tabular}{lc}
\hline Statistik Deskriptif & $\begin{array}{c}\text { Perolehan skor } \\
\text { Kelas VII }\end{array}$ \\
\hline Jumlah Siswa & 10 \\
Minimum $\left(\mathrm{X}_{\min }\right)$ & 70 \\
Maksimum $\left(\mathrm{X}_{\max }\right)$ & 100 \\
Jumlah Nilai (Sum) & 850 \\
Mean (X) & 85.00 \\
Simpangan Baku (S) & 9.718 \\
\hline
\end{tabular}

Tabel 4.5 Menunjukan bahwa pada tes akhir untuk kelas VII yang berjumlah 10 siswa diperoleh nilai terendah yaitu 70, nilai tertinggi 100,dan jumlah nilai seluruh siswa 850 dengan kemampuan rata-rata seluruh siswa 85,00 dari nilai simpangan baku yang diperoleh yaitu sebesar 9,718.

Dari data tes akhir siswa kelas VII maka diperoleh data dalam bentuk distribusi frekuensi, untuk melihat frekuensi nilai yang diperoleh pada kelas VII sebagai berikut :

Tabel 4.6 Distribusi Frekuensi Skor Akhir Siswa Kelas VII

\begin{tabular}{llcc}
\hline No & Interval & Frekuensi & Presentasi $(\%)$ \\
\hline 1 & $70-75$ & 1 & $10 \%$ \\
2 & $76-81$ & 5 & $50 \%$ \\
3 & $82-87$ & - & - \\
4 & $88-93$ & 2 & $20 \%$ \\
5 & $94-99$ & - & - \\
6 & $100-105$ & 2 & $20 \%$ \\
\hline
\end{tabular}

\begin{tabular}{lll}
\hline Jumlah & $10 \quad 100 \%$ \\
\hline
\end{tabular}

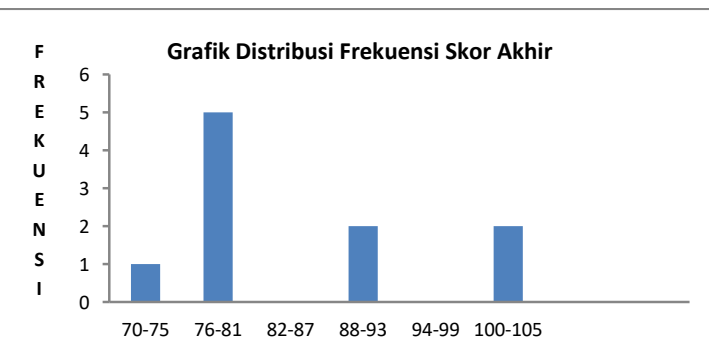

\section{Gambar 4.2 Grafik Distribusi Skor Akhir Siswa} Kelas VII

Uji validitas soal digunakan untuk mengetahui kevalidan suatu instrument. Responden yang digunakan sebanyak 10 siswa di SMP Negeri Persiapan Yenbeser yang diberi perlakuan. Berdasarkan hasil analisis menunjukkan bahwa nilai korelasi untuk soal nomor 2,3,4,5,7,8,9,10,11,12,13,14 dan $15>0,032$.

Uji reliabilitas soal dilakukan untuk mengetahui apakah sebuah instrument dapat mengukur sesuatau yang diukur secaraa konsisten dari waktu data hasil uji instrument diberlakukan kepada 10 siswa SMP Negeri Persiapan Yenbeser yang tidak mendapat perlakuan.

Hasil menunjukan bahwa reliabel dari soal ini adalah 0,796 sehingga soal tersebut dapat digunakan karena dinyatakan reliabel.

Sebelum pengolahan data lebih lanjut, maka dilakukan uji prasyarat penelitian yaitu uji normalitas berikut adalah hasil uji normalitas tes awal dan tes akhir siswa kelas VII.

Uji Normalitas dalam penelitian ini dilakukan dengan menggunakan uji Kolmogrov-Sminorv (KS), namun saat melakukan uji normalitas data tidak berdistribusi normal sehingga menggunakan uji non parametric dengan melihat hasil nilai KolmogrovSmirnov dengan asumsinya, data dikatakan berdistribusi normal apabila tiap-tiap variabel lebih besar dari $\propto=0,05$.

Berdasarkan hasil uji normalitas tes awal siswa kelas VII didapat nilainya $0,636>0,05$ dengan demikian dapat disimpulkan bahwa data tersebut berdistribusi normal.

Uji Normalitas dalam penelitian ini dilakukan dengan menggunakan uji Kolmogrov-Sminorv (KS), namun saat melakukan uji normalitas data tidak berdistribusi normal sehingga menggunakan uji non parametric dengan melihat hasil nilai KolmogrovSminorv dengan asumsinya, data dikatakan berdistribusi normal apabila tiapa-tiap variabel lebih besar dari $\propto=0,05$

Berdasarkan hasil uji normalitas tes akhir siswa kelas VII didapat nilainya $0,343>0,05$ dengan demikian dapat disimpulkan bahwa data tersebut berdistribusi normal. 
Pengujian hipotesis yang dilakukan pada penelitian ini yaitu menggunakan uji t dengan analisis uji t-test paired sampel. Hasil pengujian hipotesis dilihat pada tabel di atas.

Hasil di atas menunjukkan bahwa nilai $\mathrm{t}_{\text {hitung }}=$ 15,057. Jika dibandingkan dengan $t_{\text {tabel }}=$ 0,83311dengan df 9 maka hasil yang diperoleh yakni $\mathrm{t}_{\text {hitung }}=15,057>\mathrm{t}_{\text {tabel }}=0$,83311 yang menunjukkan bahwa $\mathrm{H}_{\mathrm{a}}$ diterima dan $\mathrm{H}_{0}$ ditolak artinya bahwa terdapat pengaruh pemanfaatan hewan invertebrata terhadap hasil belajar siswa.

Pemanfaatan hewan echinodermata sebagai media pembelajaran di gunakan dengan satu alasan hewan tersebut mudah di temukan di pinggiran pantai sampai laut yang dalam, sehingga dapat digunakan sebagai media pembelajaran untuk melihat hasil belajar dari siswa-siswi SMP Negeri Persiapan Yenbeser.

Hasil analisis dari instrumen soal menunjukkan bahwa 13 dari 15 soal dinyatakan valid, sedangkan 2 soal yang dinyatakan tidak valid akan dirubah sebelum digunakan sebagai instrument. Selain itu Uji reliabilitas diperoleh hasil yang reliabel, sehingga dapat digunakan sebagai instrument. Hasil uji normalitas menyatakan bahwa semua data berdistribusi normal, uji hipotesis yang digunakan adalah uji t-test paired sampel.

Hasil penelitian siswa kelas VII diperoleh uji normalitas data tes awal siswa kelas VII diperoleh hasil berdasarkan rumus kolmogorov-smirnov signifikan 0,636>0,05 dan pada tes akhir siswa Kelas VII diperoleh hasil berdasarkan rumus kolmogorovsmirnov signifikan 0,343>0,05 dengan demikian dapat disimpulkan bahwa data tersebut berdistibusi normal. berdasarkan uji hipotesis bahwa nilai $t_{\text {hitung }}=$ 15,057 Jika dibandingkan dengan $t_{\text {tabel }}=0,83311$, maka hasil yang diperoleh adalah $t_{\text {hitung }}=15,057>t_{\text {tabel }}$ $=0,83311$ yang menunjukan bahwa $\mathrm{H}_{\mathrm{a}}$ diterima, artinya ada pengaruh pemanfaatan hewan echinodermata terhadap hasil belajar siswa. Upaya pengaruh pembelajaran yang sedang dikembangkan, dari semua aplikasi yang dikembangkan menurut peneliti bahwa pembelajaran menggunakan spesimen hewan asli adalah salah satu media pembelajaran yang tepat yang diterapkan pada mata pelajaran IPA/Biologi karena media pembelajaran ini menuju pada pemecahan masalah dalam pembelajaran.

Hasil penelitian menggunakan spesimen hewan pada penelitian yang relevan menunjukkan bahwa hasil belajar siswa sebesar 76,67. Jumlah siswa yang tuntas sebanyak 92 siswa dan siswa yang tidak tuntas sebanyak 7 siswa. Nilai tertinggi sebesar 86,6 dan nilai terendah sebesar 54,7 .

Armi (2012), penelitian ini bertujuan untuk mengetahui jenis-jenis Echinodermata yang terdapat di Pantai Drieng Leupung. Hasil Penelitian Indentifikasi Echinodermata yang dilakukan di Kawasan Pantai Drieng leupung pada tiga stasiun diperoleh 4 kelompok kelas yaitu Holothuroidea, Echinoidea, Asteroidea, dan Ophiuroidea, sedangkan kelas Crinoidea tidak ditemukan pada ketiga stasiun. Hal ini disebabkan biota tersebut umumnya hidup di daerah tubir karang sehingga sulit untuk dikoleksi. Selama pengamatan pada tiga stasiun ditemukan 17 jenis fauna Echinodermata yang diwakili oleh 8 jenis Asteroidea, 4 jenis Echinoidea, 4 jenis Holothuroidea, dan 1 jenis Ophiuroidea.

Ruswayuni, (2014) Hasil penelitian tutupan terumbu karang dan padang lamun di Pancuran Belakang Karimunjawa di kategorikan baik yaitu dalam kisaran sebesar $55,29 \%$ dan $61,94 \%$. Jenis Echinoidea yang diketemukan pada karang dan lamun berturut-turut adalah Diadema setosum (123; 36 ind $/(150 \mathrm{~m}) 2)$, Diadema antilarum $(63 ; 18 \mathrm{ind} /(150$ m)2 , Echinothrix calamaris $(34 ; 22$ ind/(150 m)2) , Mespilia globulesa $(12 ; 0$ ind/(150 m)2 $)$ dan Echinometra mathaei (14;0 ind/(150 m)2). Uji Independent $\mathrm{T}$ Test dengan SPSS dengan taraf signifikan $5 \%, \quad \mathrm{t}$ tabel $=2,776>\mathrm{t}$ hitung $=-2,319$ sehingga $\mathrm{HO}$ diterima berarti ada perbedaan yang signifikan kelimpahan Echinoidea pada habitat karang dan lamun.

Pemanfaatan hewan echinodermata sebagai media pembelajaran meskipun terdapat beberapa kelemahan seperti diperlukan waktu yang banyak, tetapi memiliki prinsip dan keunggulan-keunggulan seperti yang berpusat pada penyelesaian masalah

1. Pada pemecahan masalah

2. Pengembangan berpikir kritis

3. Mengembangkan keterlibatan belajar

4. Mengembangkan kemampuan berpendapat

5. Mengembangkan rasa ingin tahu.

Keunggulan-keunggulan itulah pemanfaatan hewan echinodermata sebagai media pembelajaran mampu merubah situasi pembelajaran, sehingga dengan pemanfaatan spesimen hewan invertebrata sebagai media pembelajaran guru mampu merubah suatu ilustrasi menjadi suatu contoh konkrit, dan memberikan banyak kesempatan siswa untuk menstimulasikan suatu konsep.

Dengan menggunakan media ini, telah menjawab dasar perilaku guru, yaitu:

1. Mendorong siswa untuk menerima tanggung jawab

2. Kerjasama guru dan siswa berorientasi pada alternatif

\section{KESIMPULAN}

Pemanfaatan hewan echinodermata sebagai media pembelajaran di kelas VII SMP Negeri Persiapan Yenbeser memberi dampak yang positif, hal ini di buktikan dengan hasil analisis data yang termuat dalam pembahasan hasil penelitian ini.

Hasil penelitian siswa kelas VII diperoleh uji normalitas data tes awal siswa kelas VII diperoleh hasil berdasarkan rumus kolmogorov-smirnov signifikan $0,636>0,05$ dan pada tes akhir siswa Kelas 
VII diperoleh hasil berdasarkan rumus kolmogorovsmirnov signifikan 0,343>0,05 dengan demikian dapat disimpulkan bahwa data tersebut berdistibusi normal. Berdasarkan uji hipotesis bahwa nilai $\mathrm{t}_{\text {hitung }}=$ 15,057 Jika dibandingkan dengan $\mathrm{t}_{\text {tabel }}=0,83311$, maka hasil yang diperoleh adalah $\mathrm{t}_{\text {hitung }}=15,057>\mathrm{t}_{\text {tabel }}$ $=0,83311$ yang menunjukan bahwa $\mathrm{H}_{\mathrm{a}}$ diterima, artinya pemanfaatan hewan echinodermata sebagai media pembelajaran mampu meningkatkan hasil belajar siswa kelas VII SMP Negeri Persiapan Yenbeser.

\section{DAFTAR PUSTAKA}

Armi, (2012). Identifikasi Echinodermata Di Kawasan Pantai Drieng Leupung Kabupaten Aceh Besar Sebagai Media Pembelajaran Zoology Invertebrata. Jurnal Biology Education, Vol 1, No 1, Hal 31.

Arikunto, S (2008). Manajemen Penelitian, Jakarta: Asfi Mahasatya.

Andrea Garry Kambey, Unstain N.W.J.Rambet, Adnan S.Wantasen, (2015). Komunitas Echinodermata Di Daerah Intertidal Perairan Pantai Mokupa Kecamatan Tombariri Kabupaten Minahasa. Jurnal Ilmiah Platax, Vol 3, No 1, Hal 10-15.

Campbell, N. A. \& J. B. Reece. (2006). Biologi, Edisi Kedelapan Jilid 3. Terjemahan: Damaring Tyas Wulandari. Jakarta: Erlangga.

Djohar, (2006). UU Sisdiknas, Analisis UndangUndang Sisdiknas diltijau dari segi Praksis Pendidikan dan Anggaran Pendidikan.Jurnal Konstitusi Vol 3,No 1,Hal 15-34.

Diah Aryulina, Choirul Muslim, Syalfinaf Manaf, Endang Widi Winarni (2007) Biologi 1 SMA dan MA. Jakarta : Erlangga.

Eka Kurniawati, (2015) Pengembangan Majalah Biosmart Invertebrata Untuk Meningkatkan Aktivitas Dan Hasil Belajar Belajar Siswa MA.lib.unnes.ac.id

Hamalik, (2006), Proses Belajar Mengajar, Bandung Bumi Aksara.

Heni Lukitasari, (2015). Pemanfaatan media asli (specimen hewan) sebagai sumber belajar sub materi plathyhelminthes dan nemathelminthes di SMA 1 suruh. lib.unnes.ac.id.

Imah Solikhatun, Slamet Santosa, Maridi. (2015). Pengaruh Penerapan Reality Based Learning Terhadap Hasil Belajar Biologi Siswa Kelas X SMA Negeri 5 Surakarta Tahun Pelajaran 2012/2013. Jurnal Pendidikan Biologi, Vol 7, No 3, Hal 49-60.

Irwan, Z. D. (2010). Prinsip-Prinsip Ekologi. Jakarta: Bumi Aksara.
Iwenda Bella Subagio dan Aunurohim. (2013). Struktur Komunitas Spons Laut (Porifera) di Pantai Pasir Putih,Situbondo. Jurnal Sains dan Seni Pomits, Vol 2, No 2, Hal 159-165.

Kasijan Romimohtarto,Sri Juwana. (2009). Biologi Laut: Ilmu Pengetahuan Tentang Biota Laut. Jakarta: Djambatan.

Kurniawan, A. (2011). SPSS : Serba Serbi Analiss Statistika Dengan Cepat dan Mudah. Jakarta: Jasakom.

Katili Abubakar Sidik (2011) Struktur Komunitas Echinodermata Pada Zona Intertidal Di Gorontalo. Jurnal Penelitian dan Pendidikan, Vol 8, No 1, Hal 51-61.

Oktiani, R. N. (2015). Analisis teknik mencatat dalam jurnal belajar siswa kelas x pada materi animalia. Biologi Jurnal Pendidikan ,Vol 7, Hal 1-8.

Rustaman, N. (2005). Strategi Belajar Mengajar Biologi. Malang : UNM Press.

Ramlan Effendi, (2014). Konsep Revisi Taksonomi Bloom Dan Implementasinya Pada Pelajaran Matematika SMP. Jurnal Ilmiah Pendidikan Matematika: Vol 2, No 1, Hal 72-78.

Sandjaja dan Heryanto, (2006). Panduan Penelitian (edisi revisi). Jakarta: Prestasi Pustaka.

Sati Hariyanto, (2015). Buku Pintar Super Komplet Biologi. Jogjakarta: Literindo.

Satyasa, (2009). Strategi Pembelajaran, Berorientasi Kepada Standar Proses Pendidikan, Jakarta: Kencana Prenada Media Grup.

Safrida, Adrien Jems Akiles Unitly, Suprihatin (2013). Arthropoda Permukaan Tanah Pada Habitat Hutan Berbeda Ketinggian Di Kawasan Hutan Telaga Warna Puncak Bogor. Jurnal Ilmiah Pendidikan Biologi, Biologi Edukasi, Vol 5, No 1, Hal 14-17.

Sugiono, (2014) Metode Penelitian Pendidikan. Bandung: Alfabeta.

Sugiyono, (2009). Metode Penelitian Kuantitatif, Kualitatif, dan R\&D. Bandung: ALFABETA.

Sumiarti, (2009). Metode Pembelajaran. Bandung: CV Wacana Prima.

Suryanti dan Ruswahyuni, (2014) Perbedaan Kelimpahan Bulu Babi (Echinoidea) Pada Ekosistem Karang Dan Lamun Di Pancuran Belakang, Karimunjawa Jepara. Jurnal Saintek Perikanan Vol. 10 No.1 : 62-67.

Trenggonowati, (2009). Metodologi Penelitian Ekonomi dan Bisnis. Yogyakarta : BPFE.

Th. Dwiati Wismarini dkk (2014). Metode Klasifikasi Sebagai Pendukung Informasi Kelas Pada Data Indikator Banjir.

Wahyudin dkk, (2010). Pengembangan Kurikulum dan Pembelajaran. Jakarta: Universitas Terbuka. 